\title{
GREEN GDP: AN ANALYSES FOR DEVELOPING AND DEVELOPED COUNTRIES
}

\author{
Saša Stjepanović, Daniel Tomić, Marinko Škare
}

\section{Introduction}

In the push for more sustainable and greener progress, faster economic growth is no longer a priority. Is this true? There is a broad agreement that global society should strive for a higher standard of human wellbeing that is equitably shared and sustainable. Motivations for such plight are numerous; from economic (GDP measure is dangerously inadequate measure of quality of life since it counts what we produce and consume, but ignores social costs, environmental outcomes and income inequality), ecological (public is getting increasingly concerned with depleted natural resources and polluted environment, and other ecological issues), philosophical (human appetites and the population growth render non-market wellbeing measures to confront it with the society's material standard of living), political (the concept of so-called green growth is generating diversity in positions, from enthusiastic to cautious, for it can be an opportunity, but also a risk that disfavours one country on international level) to even methodological questions (the lack of recognized methodological principles that would be the basis for reliable statistical data, thus an accurate accounting and valuation system of economic growth and development).

Measuring progress on a complex and multi-dimensional scale and identifying relevant indicators are challenging tasks (Škare \& Tomić, 2014). No agreement exists yet on an analytical framework or a set of indicators to sustainable economic growth. Building the research on the alternative Green GDP measurement from Stjepanović, Tomić and Škare (2017) our goal is to provide an alternative ranking scheme by comprehensively considering both quantitative (common methodological algorithm) and qualitative (opportunity costs) features of the so-called green growth. Our analysis will be demonstrated by calculating the Green GDP indicator for the variety of developing and developed countries.

\section{Theoretical Background}

\subsection{Introduction to the Green GDP Concept}

A frequently asked question is whether the traditional measures of a country's level of economic activity and progress, such as gross domestic product (GDP), gross national product (GNP) or gross national income (GNI), fail to account for the environmental issues. For example, GDP as a prevalently used indicator of economic growth and a basis for decisionmaking and state policy elaboration is not intended to measure human wellbeing even if treated so by politicians and governments. This indicator deals only with economic output and does not consider other significant factors that affect sustainability, green growth perspectives and social. The limits of GDP are now clear: (1) it can be a misleading economic indicator if we place a disproportionate importance to it because it often reflects the material and static positions, rather than signalling what is wrong in the economy; (2) since it does not scale the sustainability of growth (it does not detect the distribution of income, household production and/or the loss of leisure time, volunteering, costs of environment degradation, social and public health costs that are in direct relation to economic activity and etc.), it is de facto a bad measure of social welfare; ( 3 ) it is a bad measure for international comparison of countries' life standard (for it tracks only our production/ consumption and it always gets better as long as we produce more or produce more valuable things. But GDP was never intended to be an all-encompassing proxy for human wellbeing (Samuelson \& Nordhaus, 2014). We must, 
however, stress that irrespective of various limitations, GDP is and will still be a crucial indicator of the economic health of a country, as well as a gauge of a country's standard of living. Is it time to dethrone GDP? No, GDP retains its value, however, it would certainly be desirable to reduce some of this dependency on it.

The rise of heterogeneous public attitude/ opinions, many forms of ecological and environmental groups, increased attention in the media and the relevance of economic costs of natural resource depletion and pollution, damages to the future growth and development perspectives, a relatively new measure of growth imposed itself as a relevant factor in measuring welfare and well-being i.e. the socalled Green GDP accounting (Stjepanović, Tomić, \& Škare, 2017). Green GDP is an alternative indicator of economic growth that incorporates environmental consequences of that growth by including the depletion of natural resources and degradation of the environment. Today, it is known as a general concept that refers to a wide array of adjusted GDP measures that are corrected for social and environmental costs (for some of these commodities are not traditionally presented in monetary units). In that manner, Green GDP is just an alternative way for quantification and measurement of monetary impact of the social and environmental damage caused by a country's economic growth. The most common approach to measuring the Green GDP is to deduct social and environmental costs (for example natural resources depletion and pollution damage) from the standard GDP measure. There is an interesting way to explain the (conceptual) purpose of this indicator. If we consider that by adding social features/ human capital and environmental features/ natural capital to a standard measure of the volume of output, we are in fact relating it to the deterioration in social or environmental capital and reducing it by the amount of capital thus consumed. Some say that we could look the other way around too. So that any improvement in social and/or environmental capital constitutes in itself a form of output and can be, therefore added to standard GDP measure. Long run causal relationship holds for the CEE countries according to the study of Obradović and Lojanica (2017).

If the GDP is a bad measure simply because it is an incomplete indicator, could we the Green
GDP as a successor to the traditional GDP. The answer is no! Though, Green GDP is not a flawed indicator, it still carries some conceptual and methodological ambiguity. In the first place, Green GDP is hard to measure because of the problems inherent in trying to evaluate and quantify the cost natural resource depletion and ecological damage. The preciseness of the Green GDP's measurement methods is debatable as some statistics that are used in calculations could be based on approximations or even speculations. Namely, this indicator faces expected problems when addressing environmental damage in monetary terms; due to estimation problems and data availability, this indicator cannot consider all damage (depletion costs for mines, water, air, forest, wildlife, etc.) to the ecosystem (for a further list of conceptual limitations see Stjepanović, Tomić, \& Škare, 2017). The concept of Green GDP is open to serious criticism even more when tackling pragmatic issues. How can one compare some social indicators such as education and health with a hectare of forest protected, a ton of $\mathrm{CO}_{2}$ emitted or adjusted savings of natural resource depletion. Depending on how you attribute values and weightings to these different factors, you can in fact obtain any ranking you want, even putting China first, or India, or France, or Brazil, or, for that matter, Niger (The Shift Project, 2012). In general, there is no consensus on how to calculate the Green GDP and there is not even a consensus on whether to attempt at all. Criteria for assessing the Green GDP as an indicator should be pointed towards evaluation of analytical soundness, measurability and policy relevance and utility for users. Green GDP only partially satisfies each one of these criteria, which leaves us with a range of possibilities pointed towards improvement of the indicator. As Pokharel and Bhandari point out (2017), although Green GDP calculation is in a very nascent stage, we have to develop an accurate accounting and valuation system, utilizing knowledge resources to develop more standardized valuation techniques for calculation of environmental costs and pollution damage. Environmental regulation is important to achieve economic growth and environmental quality (Bildirici \& Özaksoy, 2018).

\subsection{What Empirics Say?}

Interesting papers on the Green GDP topic are: provided by Vimochana (2017), Stjepanović, 
Tomić and Škare (2017), Veklych and Shlapak (2013), Rauch and Chi (2010), Jiang (2007), Alfsen et al. (2006), and Boyd (2006). For a deeper systematization of the early contributions, theoretical as well as empirical, see Qi, Xu and Coggins (2001). Complexities that evolve around the Green GDP induce empirical domain that is conceptually rather intriguing. For many empirical studies approach from different standpoints that consider different lines of inquiry; microeconomic view (companies positions), green accounting system, political standpoints and decision making and environmental, technical as well as organizational issues (for example see $\mathrm{Li}$ et al., 2018; Medialdea, 2018; Sánchez García \& Díez Sanz, 2018; Peres, Ameer, \& Xu, 2018; Esmaeili et al., 2017; Gkorezis \& Petridou, 2017; Mikušová, 2017; and Štreimikienè \& Mikalauskienè, 2016). For our line of research there are few papers, besides that of Stjepanović, Tomić and Škare (2017), that are empirically curious.

Vimochana (2017) analyzed the role of environmental accounting and the policy options available for economic decision makers by reviewing the methods of valuation of natural resources adopted by various developed and developing countries. Author came to conclusion that the adoption of basic elements of green accounting will portray the role of environment in the economy as well as render easier the analysis of macroeconomic questions with the help of accounting information system and thus, lead the economy to a vital path. The research that is conceptually related to our study is that of Qi, Xu and Coggins (2001) for it is the only comprehensive and extensive research of the Green GDP on a cross-country base. The authors calculated the value of environmental damage as a percentage of GDP and Green GDP for a sample of 103 developed countries and developing countries for the period 1980-1997. The authors came to conclusion that most of the countries have not worsened their environmental quality in order to achieve the gains of GDP (even if we take into the account countries that are in their early development stages).

\section{$1.3 \mathrm{~W}(\mathrm{~h})$ ither Green GDP Indicator; Some Methodological Issues}

According to the different accounting systems, green GDP can be classified as two main types (see for example Xu, Yu, \& Yue, 2010). Type I Green GDP accounts GDP minus the cost of environmental pollution and resources depletion, but it ignored the value of natural ecosystem services. In such context, more and more scholars are beginning to account the valuation of ecosystem services by adding it into GDP accounting, which the authors present as a type II Green GDP. This adds to broadening of methodological issues and solutions. Furthermore, when taking into account SEEA standards (UN System of EnvironmentalEconomic Accounting), we can distinguish data on environmental inputs and resources as those fitting into physical and hybrid flow accounts. These accounts show the dependency of the economy on the environmental inputs as well as the sensitivity of the environment to the economic activities. The problem begins when we want to extend the SNA (System of National Accounts) aggregates to account for depletion, natural degradation and pollution costs. It is the point in which you come across feasible barriers (Costanza et al., 2009) to measuring real progress of the economy, such as data barriers (data reliability, timeliness, scope and scale), methodological barriers (methodology standardization, the values embedded in the type of approach that reflects social choices), social and institutional barriers (dominance of 'Growth is good' paradigm, lack of political leadership, 'aspiring' to status-quo). It is also the point related to the process of gauging the indicator (see for example Rauch \& Chi, 2010). For that purpose, Veklych and Shlapak (2013) evaluated three methodological approaches to the environmentally adjusted domestic product calculation; (1) includes the consideration of the reduction of natural capital; (2) takes into account the environmental degradation due to the accumulation of pollutants and waste, as they have an effect on both economic activity and natural capital; (3) supposes further deduction of the costs spent on combating environmental degradation because defensive expenditures should be displayed in these adjusted accounts depending on their impact on natural capital. From a standpoint of short-term assessment, the accounting of a complete - comprehensive indicator is impossible (Jinnan, Hongqiang, \& Fang, 2004), however in the medium to longterm, monitoring of economic progress will require both an indicator of total growth (that can be observed through traditional GDP) and an 
indicator of how a country's real comprehensive wealth, that includes natural, social and human capital, is changing (could be evaluated through the Green GDP) (Stjepanović, Tomić, \& Škare, 2017).

A misconception that economic development and growth would eventually lead to environmental sustainability, the fact that developed countries consume more resources per capita than developing countries and that ecological/economic impact are felt in other places, implies that Green GDP has a potential to serve as a metric for sustainable progress policy as well as measure the strength of the means of implementations (policies or programmes) for promoting sustainability.

\section{Methodological Part and the Results}

\subsection{Data and Methodology}

Stjepanović, Tomić and Škare in 2017 proposed an alternative approach to sustainability and green growth, which represents a crucial step towards transforming the global economic thinking, by ensuring applicable methodology and correct information for the assessment of economic progress. By following their work and keeping common Green GDP accounting framework (a quantitative position), we have applied a general methodological algorithm that is suitable for the assessment of and comparison between different countries, as well as other surveys. Hence, the Green GDP indicator is calculated as a GDP measure minus the cost of natural resource consumption minus the costs of environmental depletion. On the other part, we have also considered the importance of economic dimensions that are not sufficiently reflected in the traditional GDP measure or even in different 'green growth' approaches so we integrated supplementary information (a qualitative position) by distinguishing the real costs of environmental damage and opportunity costs of a lost turnover.

Data for a sample of 44 countries, that includes both developing and developed countries, has been collected from Eurostat and World Development Indicators database of the World Bank (with some specific indices from other sources). The analysis covers 44 countries of the world (EU countries and potential members, part of the OECD countries and some selected countries) for the time span 2008-2016. Data (un)availability was a major obstacle in achieving more extensive research on a cross-country base. A general scheme of calculation (presented by Stjepanović, Tomić and Škare, 2017) is Green GDP $=$ GDP $-\left(\mathrm{CO}_{2}\right.$ emissions in kt $x$ total CDM in average prices for $\mathrm{kt}$ ) - (t of waste $x 74 \mathrm{kWh}$ of electrical energy $x$ price for $1 \mathrm{kWh}$ of electrical energy) - (GNI/100 $x$ natural resources depletion \% of GNI); or expressed simplified as:

$$
\begin{aligned}
& \text { Green GDP }=\text { GDP }-\left(\mathrm{KtCO}_{2} * \mathrm{PCDM}\right)- \\
& -(\text { Twaste } * 74 \mathrm{kWh} * \text { Pelect })- \\
& -\left(\frac{G N I}{100} * \% N R D\right)
\end{aligned}
$$

GDP (in PPP) was obtained as the sum of gross value added by all resident producers in one economy plus any product taxes minus any subsidies not included in the value of the products. It has been calculated without making deductions for depreciation of fabricated assets or depletion and degradation of natural resources (WDI, 2017). The first deduction presents the costs of $\mathrm{CO}_{2}$ pollution (as $\mathrm{CO}_{2}$ emissions times carbon market price), second the opportunity costs of one tonne of waste that could be used in the production of electrical energy), and a third is the adjusted savings of natural resource depletion as a percentage of the gross national income per country.

Carbon dioxide emissions $\left(\mathrm{CO}_{2}\right)$ expressed as kilotonnes $(\boldsymbol{K} \boldsymbol{t})$ are those stemming from the burning of fossil fuels and the manufacture of cement. They include carbon dioxide produced during consumption of solid, liquid, and gas fuels and gas flaring (WDI, 2017). Total $\boldsymbol{P C D M}$ is the average volume-weighted price for carbon in PPP (Capoor \& Ambrosi, 2007). Total commercial and industrial waste (Twaste) is presented in tonnes and data were partially collected from the Eurostat and from the World Bank database. In order to evaluate opportunity costs related to waste problems, knowing that the amount of waste nations produce annually is huge, we introduced a waste-to-energy conversion principle. Hence, kilowatts $(\boldsymbol{k W})$ of energy in one tonne of waste present an amount of electrical energy that we can derive from waste. Namely, $74 \mathbf{k W h}$ is kilowatts-hours of energy in one tonne of waste present an amount of electrical energy that can be obtained from a waste (according to Australian Energy Regulator, 2015; and Waste 
to energy in Denmark, 2006). Price (Pelect) in PPP for 1 kilowatt-hour is calculated as a mean of commercial and industrial price for each country (Eurostat, 2017). Gross national income or GNI (in current U.S. dollars) is the sum of value added by all resident producers plus any product taxes (less subsidies) not included in the valuation of output plus net receipts of primary income (compensation of employees and property income) from abroad (WDI, 2017). Finally, variable adjusted savings of natural resource depletion (NRD), as a percentage of the GNI per country, presents natural resource depletion as a sum of net forest depletion, energy depletion, and mineral depletion (WDI, 2017).

\subsection{Results}

Results from Tab. 1 present the difference in percentage between the value of the traditional GDP measure and the value of calculated Green GDP measure for the observed countries as a deviation from the GDP. For example, if you want to obtain the Green GDP value for Belgium in 2016 you would have deflate the GDP value for $0.38 \%$. Average deviation from the GDP for all the countries and for the whole period was $1.45 \%$. This implies that growth in these countries during the observed period was not satisfactory in the terms of sustainable economic development. The most satisfactory results (for the period as a whole), hence the smallest deviation on average $(<0.60 \%)$ between the GDP and Green GDP growth was found in Belgium $(0.43 \%)$, Switzerland $(0.13 \%)$, Germany $(0.41 \%)$, Greece $(0.57 \%)$, Ireland $(0.27 \%)$, Spain $(0.34 \%)$, France $(0.24 \%)$, Italy (0.45\%), Cyprus $(0.44 \%)$, Luxembourg $(0.29 \%)$, Austria $(0.54 \%)$, Portugal $(0.53 \%)$, Slovenia $(0.56 \%)$, the Slovak Republic $(0.57 \%)$, Japan $(0.35 \%)$ and Israel $(0.47 \%)$. Next, average deviation below $1.00 \%$ was found in the Czech Republic $(0.91 \%)$, Lithuania $(0.64 \%)$, Hungary $(0.82 \%)$, Malta $(0.93 \%)$, the Netherlands $(0.96 \%)$, Finland $(0.89 \%)$, Sweden $(0.65 \%)$, the United Kingdom $(0.91 \%)$, Turkey $(0.76 \%)$ and the United States $(0.87 \%)$, suggesting relatively satisfying results. Other category is above $1.00 \%$ deviations with unsatisfactory results. Those are, Croatia (1.01\%), Montenegro (1.06\%), Moldova (1.14\%), Iceland (1.16\%), Latvia (1.26\%), Poland (1.29\%), Denmark (1.44\%), Romania (1.64\%), Estonia $(1.70 \%)$ and Serbia (1.87\%). In absolute global terms (with largest average deviations), 8 countries with the worst environmental impact are (in order, worst first) Chile $(8.88 \%)$, Norway $(6.56 \%)$, China (5.02\%), Mexico (4.33\%), Macedonia FYR (3.46\%), Australia (2.96\%), Bulgaria $(2.17 \%)$ and Albania (2.06\%). We can conclude that the most satisfactory countries, by the standard of sustainable development (seen through the smallest difference in GDP vs. Green GDP), are in fact coming from one of the most developed areas in the world, the EU. For some of these countries, economic growth was more limited (smaller growth rates), but their Green GDP seems to have risen faster than the standard measure. Though we trace relatively consistent deviations over the whole period, some improvements, i.e. smaller bias has been achieved in most of the developed countries that have shown unsatisfactory results in the beginning of the period. We have to mention that Chile, Norway and especially China show a persistent decrease in the deviation between the GDP and Green GDP.

Next, we are going to give some insight on the annual growth rates of the GDP and Green GDP across all 44 countries (see Tab. 3 in the Appendix) and provide a comparative analysis of different groups of countries by presenting their average growth rates for the period as a whole (see Tab. 2). Additionally, we displayed annual growth rates of these two indicators for the year 2016 (see Fig. 1) in order to confirm the analogy in our concluding arguments. If we group countries by their stage of development we get three standards groups, namely developed, developing and underdeveloped countries. Developed countries (Belgium, Denmark, Germany, Ireland, Greece, Spain, France, Italy, Cyprus, Luxemburg, Malta, the Netherlands, Austria, Portugal, Finland, Sweden, the UK, Iceland, Norway, the USA, Australia, Japan, Israel, Switzerland (24)), developing countries (Bulgaria, the Czech Rep., Estonia, Croatia, Latvia, Lithuania, Hungary, Poland, Romania, Slovenia, Slovakia, Montenegro, Serbia, Turkey, Moldova, Chile, China, Mexico (18)) and underdeveloped countries (FYR Macedonia, Albania (2)). Such categorization is arbitrary and is made purely for the purpose of distinct comparative analysis.

First, let us focus on developed countries. The average GDP growth and Green GDP growth (average for the period as a whole) for the developed countries was $-0.42 \%$ and 


\section{Tab. 1: Average bias of the Green GDP (Part 1)}

\begin{tabular}{|c|c|c|c|c|c|c|c|c|c|}
\hline $\begin{array}{c}\text { Deviations from } \\
\text { the GDP (in \%) }\end{array}$ & 2008 & 2009 & 2010 & 2011 & 2012 & 2013 & 2014 & 2015 & 2016 \\
\hline Belgium & -0.44 & -0.58 & -0.70 & -0.35 & -0.36 & -0.35 & -0.33 & -0.38 & -0.38 \\
\hline Bulgaria & -2.33 & -1.79 & -2.28 & -2.42 & -2.40 & -1.97 & -1.92 & -2.18 & -2.27 \\
\hline Czech Rep. & -1.08 & -0.90 & -1.00 & -0.94 & -0.87 & -0.79 & -0.79 & -0.90 & -0.90 \\
\hline Denmark & -2.00 & -1.37 & -1.56 & -1.76 & -1.80 & -1.41 & -1.19 & -0.94 & -0.97 \\
\hline Estonia & -1.46 & -1.57 & -1.97 & -1.75 & -1.72 & -1.71 & -1.58 & -1.80 & -1.72 \\
\hline Germany & -0.44 & -0.41 & -0.43 & -0.40 & -0.42 & -0.39 & -0.36 & -0.40 & -0.41 \\
\hline Greece & -0.55 & -0.46 & -0.55 & -0.61 & -0.65 & -0.55 & -0.55 & -0.61 & -0.64 \\
\hline Ireland & -0.26 & -0.27 & -0.35 & -0.30 & -0.29 & -0.27 & -0.26 & -0.20 & -0.23 \\
\hline Spain & -0.32 & -0.32 & -0.33 & -0.33 & -0.37 & -0.33 & -0.32 & -0.38 & -0.41 \\
\hline France & -0.24 & -0.25 & -0.26 & -0.23 & -0.25 & -0.24 & -0.21 & -0.25 & -0.27 \\
\hline Croatia & -0.87 & -1.09 & -0.88 & -0.90 & -1.29 & -1.06 & -0.98 & -1.00 & -1.04 \\
\hline Italy & -0.43 & -0.40 & -0.43 & -0.43 & -0.49 & -0.46 & -0.42 & -0.46 & -0.49 \\
\hline Cyprus & -0.42 & -0.45 & -0.44 & -0.42 & -0.43 & -0.38 & -0.40 & -0.47 & -0.50 \\
\hline Latvia & -0.97 & -1.47 & -1.51 & -1.18 & -1.14 & -1.09 & -1.10 & -1.40 & -1.45 \\
\hline Lithuania & -0.63 & -0.65 & -0.71 & -0.63 & -0.66 & -0.57 & -0.56 & -0.65 & -0.67 \\
\hline Luxembourg & -0.34 & -0.32 & -0.32 & -0.31 & -0.31 & -0.26 & -0.24 & -0.28 & -0.28 \\
\hline Hungary & -0.83 & -0.88 & -0.83 & -0.86 & -0.95 & -0.80 & -0.74 & -0.73 & -0.76 \\
\hline Malta & -1.14 & -0.94 & -0.86 & -0.97 & -0.94 & -0.83 & -0.80 & -0.94 & -0.95 \\
\hline Netherlands & -0.97 & -0.92 & -0.72 & -0.86 & -1.31 & -1.22 & -1.02 & -0.81 & -0.82 \\
\hline Austria & -0.53 & -0.50 & -0.56 & -0.54 & -0.58 & -0.55 & -0.50 & -0.54 & -0.54 \\
\hline Poland & -1.26 & -1.31 & -1.36 & -1.36 & -1.35 & -1.21 & -1.13 & -1.26 & -1.37 \\
\hline Portugal & -0.51 & -0.52 & -0.52 & -0.53 & -0.55 & -0.51 & -0.50 & -0.55 & -0.57 \\
\hline Romania & -1.77 & -1.49 & -1.57 & -1.95 & -2.19 & -1.65 & -1.48 & -1.30 & -1.32 \\
\hline Slovenia & -0.55 & -0.54 & -0.59 & -0.56 & -0.58 & -0.54 & -0.47 & -0.58 & -0.59 \\
\hline Slovak Rep. & -0.58 & -0.58 & -0.65 & -0.56 & -0.57 & -0.54 & -0.50 & -0.58 & -0.60 \\
\hline Finland & -0.79 & -0.69 & -0.97 & -0.99 & -0.96 & -0.85 & -0.83 & -0.93 & -0.96 \\
\hline Sweden & -0.60 & -0.60 & -0.74 & -0.66 & -0.62 & -0.62 & -0.57 & -0.71 & -0.72 \\
\hline UK & -1.23 & -1.05 & -1.09 & -1.14 & -1.01 & -0.86 & -0.68 & -0.52 & -0.61 \\
\hline Iceland & -0.91 & -1.51 & -1.14 & -1.06 & -1.12 & -1.18 & -1.09 & -1.26 & -1.15 \\
\hline Norway & -9.09 & -7.38 & -6.44 & -6.88 & -6.70 & -5.67 & -6.04 & -5.25 & -5.58 \\
\hline Montenegro & -1.25 & -0.82 & -1.20 & -1.14 & -1.10 & -0.93 & -0.96 & -1.05 & -1.10 \\
\hline Macedonia & -3.38 & -2.34 & -3.63 & -3.77 & -3.72 & -3.29 & -3.24 & -3.93 & -3.81 \\
\hline Albania & -0.97 & -0.87 & -1.51 & -2.36 & -2.69 & -2.91 & -3.00 & -2.06 & -2.14 \\
\hline Serbia & -1.90 & -1.73 & -2.14 & -2.13 & -2.12 & -1.73 & -1.50 & -1.82 & -1.79 \\
\hline Turkey & -0.70 & -0.75 & -0.73 & -0.82 & -0.80 & -0.71 & -0.72 & -0.80 & -0.84 \\
\hline Moldova & -1.04 & -1.10 & -1.17 & -1.01 & -0.98 & -1.07 & -1.09 & -1.41 & -1.38 \\
\hline United States & -1.66 & -0.89 & -0.90 & -0.93 & -0.80 & -0.81 & -0.82 & -0.52 & -0.51 \\
\hline
\end{tabular}


Tab. 1: Average bias of the Green GDP (Part 2)

\begin{tabular}{l|c|c|c|c|c|c|c|c|c}
$\begin{array}{c}\text { Deviations from } \\
\text { the GDP (in \%) }\end{array}$ & $\mathbf{2 0 0 8}$ & $\mathbf{2 0 0 9}$ & $\mathbf{2 0 1 0}$ & $\mathbf{2 0 1 1}$ & $\mathbf{2 0 1 2}$ & $\mathbf{2 0 1 3}$ & $\mathbf{2 0 1 4}$ & $\mathbf{2 0 1 5}$ & $\mathbf{2 0 1 6}$ \\
\hline Australia & -4.39 & -3.33 & -3.54 & -3.43 & -2.64 & -2.55 & -2.64 & -1.92 & -2.21 \\
\hline Japan & -0.34 & -0.30 & -0.31 & -0.29 & -0.30 & -0.36 & -0.38 & -0.43 & -0.43 \\
\hline China & -12.56 & -5.88 & -6.10 & -6.09 & -4.19 & -3.47 & -2.70 & -2.01 & -2.16 \\
\hline Chile & -9.08 & -8.51 & -10.10 & -9.13 & -8.57 & -7.89 & -8.53 & -8.91 & -9.18 \\
\hline Israel & -0.65 & -0.47 & -0.43 & -0.45 & -0.51 & -0.48 & -0.43 & -0.43 & -0.42 \\
\hline Mexico & -5.61 & -4.02 & -4.33 & -5.60 & -5.57 & -4.70 & -3.97 & -2.42 & -2.78 \\
\hline Switzerland & -0.16 & -0.16 & -0.15 & -0.12 & -0.13 & -0.13 & -0.11 & -0.13 & -0.13 \\
\hline
\end{tabular}

Source: Authors' calculation

$-1.34 \%$ (difference $0.92 \%$ ). Negative average growth rates of both indicators were probably the results of the ongoing adjustment of the world economy on the aftermaths of the Economic crisis of 2008, since the sample includes those economically volatile years. If we analyze developed countries as those represented as 'High income OECD members' (as determined by the World Bank), we notice that the difference between the average GDP growth and Green GDP growth was $0.95 \%$. When we take into account so-called 'IMF advanced economies' (according to the International Monetary Fund) we found the difference between the two indicators of $1.04 \%$. If we take into consideration the 'HDI top 25 countries' (ranked by the United Nations), there is a difference between the average GDP growth rate and the Green GDP growth of $0.91 \%$. We marked relatively similar results. There is a general standpoint that as wealth increases, countries have more access to the clean technology and eventually become more environmentally aware so that the negative environmental impart start to decline. This can be, at least partially accepted, as a reasonable argument, especially if we focus on some of the most developed parts of the world. For example, the average difference of GDP growth and Green GDP growth for the EU-28 was only $0.81 \%$, for the Euro Area countries it was $0.64 \%$, and for the EU 6 Founding members it was only $0.46 \%$. When observing the United States, despite its resistance towards some global ecological trends, we found the difference of $0.77 \%$. For other developed countries, the difference was even lower; in
Israel (0.45\%), Japan (0.35\%) and Switzerland $(0.13 \%)$. These results do not confirm pervasive thinking that economic progress will, usually, lead to economic sustainability, however, developed and high-income countries appear to support a more sustainable economic behaviour and lifestyle, even though in practice they consume more resources per capita than the other countries (we will use this argument later again). Generally, we concluded that the most satisfactory results, by the standard of sustainable economic progress, are de facto coming from most developed parts of the globe.

When we turn to the developing countries the difference between the average growth of GDP and the average Green GDP growth on the whole periods, tends to grow. The average difference between the two indicators for the developing countries was $0.10 \%$ and $-1.82 \%$ (difference 1.92\%). When we look at the Ex-Communists countries (the Czech Rep., Bulgaria, Estonia, Croatia, Latvia, Lithuania, Hungary, Poland, Romania, Slovenia, Slovakia, Montenegro, FYR Macedonia, Serbia and Moldova) and Ex-Yugoslavian countries (Croatia, Slovenia, Montenegro, FYR Macedonia and Serbia) we found a difference an average difference of $1.34 \%$ and $1.59 \%$. All the values for these countries are around the sample average, suggesting that their average annual Green GDP growth rates are reflecting the current state of the problem. If we consider FYR Macedonia and Albania as underdeveloped countries, we get to relatively high difference of an average of $2.83 \%$. This implies that environmental quality and the process of economic development grows with 
the development stages or, on the other hand, that the countries on the lower development stages tend to go in favour of higher current growth rates against sustainable economic progress. It also means that these countries, both developing and underdeveloped, are not on a path to sustainable development even if their economies, according to the real GDP, appear to be growing.

How about those inglorious examples? Who are the under-performers in this category? Again, the world's 8 worst environmental performers according to the sustainability criterion (based on the difference between the average GDP growth and Green GDP growth for the whole period are (in order, worst first): Chile (8.85\%), Norway $(6.24 \%)$, Mexico $(4.17 \%)$, China $(4.08 \%)$, Macedonia FYR (3.47\%), Australia (2.78\%), Albania (2.19\%) and Bulgaria $(2.15 \%)$. Though most of the high-income countries often rely more on nonextractive industries such as manufacturing and service sector and low-income countries depend more on extractive industries (and this is probably an acceptable argument on the global scale), we noticed that these 8 underperformers are this high on scale because they consume more resources per capita as they feed their economic growth. In order to provide a more insightful analysis on the real source of their unsustainable development of these, relatively distinct countries, we would have to get into wider discussion that goes beyond traditional economic analysis. None-the-less, for some countries we will have to wait to see if the Environmental Kuznets curve holds, i.e. will the ecological and environmental quality of life improve as the economy grows towards higher income levels.

Overall, we found consistent dynamics of the deviation between the growth rates of Green GDP and the traditional measure of GDP over the whole period. Growth rate dynamics have not differed significantly through the observed period in almost all countries, equally between the countries in the same groupings and in between different categories of countries. We can conclude that in most of the countries environmental quality has been sacrificed for achieving higher growth rates and higher benefits of standard economic features. Countries on higher levels of development tend to have more concern for the environment, ecosystems (also high life expectancy and

\section{Tab. 2: Average growth rates across different categories for the whole period}

\begin{tabular}{l|c|c|c}
\multicolumn{1}{c|}{ Average growth rates in \% (2008-2016) } & GDP & Green GDP & Difference \\
\hline Average (all countries) & -0.17 & -1.59 & 1.42 \\
\hline DEVELOPED COUNTRIES & -0.19 & -1.14 & 0.95 \\
\hline High income OECD countries & -2.58 & -1.54 & 1.04 \\
\hline IMF advanced economies & -0.11 & -1.02 & 0.91 \\
\hline HDI Index 25 first countries & -1.02 & -2.36 & 1.34 \\
\hline EUROPEAN COUNTRIES & -1.45 & -3.04 & 1.59 \\
\hline Ex-Communist EU countries & -1.45 & -2.26 & 0.81 \\
\hline EX-Yugoslavian countries & -1.52 & -2.16 & 0.64 \\
\hline EU 28 & -1.25 & -1.71 & 0.46 \\
\hline Euro Area & & & \\
\hline EU 6 Founding countries & -0.42 & -1.34 & 0.92 \\
\hline COUNTRIES BY DEVELOPMENT & 0.10 & -1.82 & 1.92 \\
\hline Developed countries & 0.38 & -2.45 & 2.83 \\
\hline Developing countries &
\end{tabular}


greater health care) and all those issues are incorporated in the dynamics of the Green GDP even though this indicator cannot evaluate and accurately measure it in total. The top performing economies react to green opportunities better as they acknowledge that (future) green growth will be more vital than ever. On the other hand, most of the developing countries still struggle to reach similar path. The overall results reveal both encouraging signs and worrisome trends relevant national and global policy-makers and the society as it illuminates the actual progress (ambition) towards green growth economy. Finally, we have to be very careful in interpretation, manipulation and usage of these results because they correspond to the specific period and selective/arbitrary methodology.

\section{Beyond Conclusion}

Methodology and methodological bases for monitoring the number of socio-economic indicators mainly exists in the form of, literary, conceptual proposals and approximations. They are not universally applied by important international institutions, nor enshrined in countries' laws, however they are commonly used in the society to describe social innovations in every aspect of human development. One such concept is the socalled Green GDP; pointing that the depletion of natural resources or increases in pollution should be factored in traditional GDP measure as to arrive at a real sense of sustainability of national growth and development, which is de facto Green GDP assessment. Due to its methodological limitations and interpretation scantiness, Green GDP cannot replace traditional GDP measure, nor will it substitute other measures of sustainable development, but should be seen as an attempt in contemplating one unavoidable feature of economic progress, the sustainability. The Green GDP indicator has become a measure of awareness by which myriad public protagonists are trying to enforce new, 'environmentally attributed' policy orientation. While the Green GDP accounting is not yet a widely accepted concept, for it is methodologically complex and (socio-economically speaking) complicated and questionable system, the improvement in theories and methods is still speeding up (Stjepanović, Tomić, \& Škare, 2017). It is going to be a challenging task, especially in the field of statistics, for many developing and undeveloped countries still do not have vital statistics, let alone environmental statistics.

\section{Fig. 1: GDP growth (\%) vs. green GDP growth (\%) in 2016}

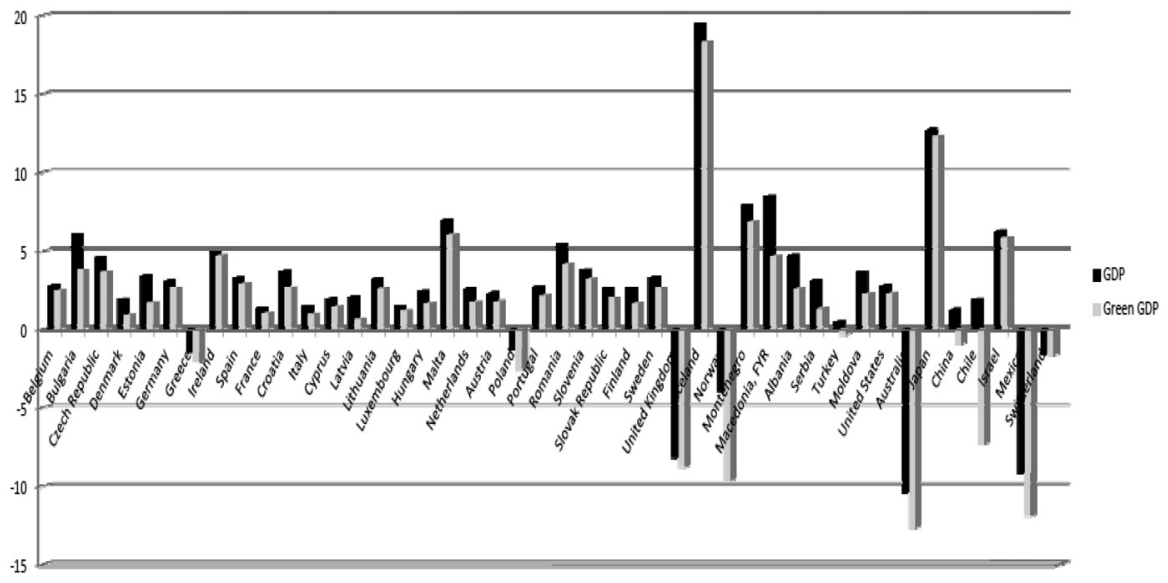


Our analysis provided an alternative ranking scheme by comprehensively considering both quantitative (common methodological algorithm) and qualitative (opportunity costs) features of green growth and sustainable development for the variety of developing and developed countries for the period 2008-2016. We concluded that the most satisfactory results, by the standard of sustainable development (seen through the smallest difference in GDP growth vs. Green GDP), are coming from one of the most developed areas in the world, the United States and developed countries of the EU. We also found consistent dynamics of the deviation between the growth rates of Green GDP and the traditional measure of GDP through the observed period in almost all countries. Finally, we came to the conclusion that in most of the countries' environmental quality has been sacrificed for achieving higher growth rates and higher benefits of standard economic features. It is obvious that our study does not claim to fully satisfy the question regarding the international comparability within growth perspectives and we also understand the uncertainty with reference to the accuracy of the presented methodology because of the existing limitation in data management and green growth identification. However, we offered results arising from the new/alternative approach of Green GDP identification as a way to initiate institutional interaction with important issues within the society. Namely, our results could serve to improve the level of debate on different green indicators and inform the wider public. We see this paper as a step forward for a growing academic platform on 'green economy topics', a step pointed towards improving, amending, evolving and promoting further development of green growth measurements and perorations.

\section{References}

Alfsen, K. H., Hass, J. L., Tao, H., \& You, W. (2006). International experiences with 'green GDP'. Reports 2006/32, Statistics Norway.

Australian Energy Regulator. (2015). National Greenhouse accounts factors; Australian National Greenhouse Accounts. Australian Energy Regulator and Department of Environment of Australia, Commonwealth of Australia. Retrieved November 9, 2018, from https://www.environment.gov.au/system/ files/resources/80f603e7-175b-4f97-8a9b2d207f46594a/files/national-greenhouseaccounts-factors-july-2018.pdf.

Bildirici, M., \& Özaksoy, F. (2018). An analysis of biomass consumption and economic growth in transition countries, Economic Research-Ekonomska Istraživanja, 31(1), 386-405. http://doi.org/10.1080/133167 7X.2018.1427610.

Boyd, J. (2009). Green GDP: 'Seeing' the Hidden Economy of Nature. Resources for the Future, a part of Research Paper 09-35 with Alan Krupnick. Washington, DC. Retrieved November 9, 2018, from http://www.cirano. qc.ca/icirano/public/pdf/GDPMontreal2.pdf.

Boyd, J. (2006). The Nonmarket Benefits of Nature: What Should Be Counted in Green GDP? Ecological Economics, 61(4), 716-723. https://doi.org/10.1016/j.ecolecon.2006.06.016.

Capoor, K., \& Ambrosi, P. (2007). State and Trends of the Carbon Market 2007. World Bank Institute, World Bank. Retrieved November 8, 2017, from http://documents.worldbank.org/ curated/en/416871468138574709/State-andtrends-of-the-carbon-market-2007.

Constanza, R., Hart, M., Talberth, J., \& Posner, S. (2009). Beyond GDP: The Need for New Measure of Progress. The Pardee Papers No. 4, Boston, MA: Frederick S. Pardee Center for the Study of the Longer-Range Future.

Esmaeili, A., Sepahvand, A., Rostamzadeh, R., Joksiene, I., \& Antucheviciene, J. (2017). Effect of integration of green constructs and traditional constructs of brand on green purchase intention of customers. E\&M Economics and Management, 20(3), 219-237. http://doi.org/10.15240/tul/001/2017-3-015.

Eurostat (2017). Official EU statistical data. Retrieved November 9, 2018, from http://ec.europa.eu/eurostat.

Gkorezis, P., \& Petridou, E. (2017). Corporate social responsibility and proenvironmental behaviour: organisational identification as a mediator. European Journal of International Management, 11(1), 1-18. https://doi.org/10.1504/EJIM.2017.081248.

Jiang, W. (2007). China Debates Green GDP and its Future Development mode. China Brief, 7(16), 4-6.

Jinnan, W., Hongqiang, J., \& Fang, Y. (2004). Green GDP Accounting in China: Review and Outlook. Paper presented at the Ninth London Group of Environmental Accounting, Copenhagen. Retrieved November 8, 2017, 
from http://mdgs.un.org/unsd/envAccounting/ londongroup/meeting9/china_country_ report_2004.pdf.

Li, P. Y., Huang, K. F., Xu, K., \& Yu, C. M. J. (2018). The effect of local environment on innovation: a comparison of local and foreign firms in China. European Journal of International Management, 12(4), 447-471. https://doi.org/10.1504/EJIM.2018.092845.

Medialdea, J. T., Ruiz, J. A. P., García, C. F., Capilla, A. C., Martorell, J. C., \& Rodenas, J. B. (2018). Potential of science to address the hunger issue: Ecology, biotechnology, cattle breeding and the large pantry of the sea. Journal of Innovation \& Knowledge, 3(2), 82-89. https://doi.org/10.1016/j.jik.2017.12.007.

Mikušová, M. (2017). To be or not to be a business responsible for sustainable development? Survey from small Czech businesses. Economic Research - Ekonomska istraživanja, 30(1), 1318-1338. https://doi.org/1 0.1080/1331677X.2017.1355257.

Obradović, S., \& Lojanica, N. (2017). Energy use, $\mathrm{CO}_{2}$ emissions and economic growth - causality on a sample of SEE countries, Economic Research-Ekonomska Istraživanja, 30(1), 511-526. http://doi.org/10.1080/133167 7X.2017.1305785.

Pokharel, S. B., \& Bhandari, B. P. (2017). Green GDP: Sustainable Development. The Himalayan Times. Retrieved from https://thehimalayantimes.com/opinion/greengdp-sustainable-development/.

Qi, S., Xu, L., \& Coggins, J. S. (2001). Integrated Environmental-Economic Accounting of GDP. Paper provided by Agricultural and Applied Economics Association in its series - Annual meeting of the American Agricultural Economics Association in Chicago. Retrieved November 8, 2017, fromhttps://pdfs.semanticscholar.org/824c/ 535f30ad619589781dc6301c52ffba229618.pdf.

Peres, M., Ameer, W., \& Xu, H. (2018). The impact of institutional quality on foreign direct investment inflows: evidence for developed and developing countries. Economic Research Ekonomska istraživanja, 31(1), 626-644. https:// doi.org/10.1080/1331677X.2018.1438906.
Rauch, J. N., \& Chi, Y. F. (2010). The Plight of Green GDP in China. Consilience: The Journal of Sustainable Development, 3(1), 102116. https://doi.org/10.7916/D8FX794J.

Sánchez García, J. L., \& Díez Sanz, J. M. (2018). Climate change, ethics and sustainability: An innovative approach. Journal of Innovation \& Knowledge, 3(2), 70-75. https://doi.org/https://doi.org/10.1016/j. jik.2017.12.002.

Stjepanović, S., Tomić, D., \& Škare, M. (2017). A New Approach to Measuring Green GDP: A Cross-country Analysis. Entrepreneurship and Sustainability Issues, 4(4), 574-590. http://dx.doi.org/10.9770/ jesi.2017.4.4(13).

Škare, M., \& Tomić, D. (2014). Examining the Link between Innovation, Productivity and Growth: a Global View. Amfiteatru Economic Journal, 16(36), 606-624. Retrieved November 8, 2017, from http://www.amfiteatrueconomic. ro/temp/Article_1295.pdf.

Štreimikienè, D., \& Mikalauskienè, A. (2016). Green growth and use of EU structural funds in Baltic states, Czech Republic and Slovakia. E\&M Economics and Management, 19(2), 55-72. https://doi.org/10.15240/ tul/001/2016-2-004.

The Shift Project. (2012). Is the Green GDP a Flawed Index? The Carbon Transition Think Tank. Retrieved November 8, 2017, from https://theshiftproject.org/en/article/is-thegreen-gdp-a-flawed-index/.

Veklych, O., \& Shlapak, M. (2013). Green GDP as an indicator of environmental cost of economic growth in Ukraine. Retrieved November 8, 2017, from https://archive.org/ stream/GreenGdpAsAnIndicatorOfEnvironmental CostOfEconomicGrowthInUkraine/Veklych. Shlapak. GreenGdpAsAnIndicatorOf EnvironmentalCostOfEconomicGrowthOf Ukraine_djvu.txt.

Vimochana, M. (2017). Green GDP calculations in developed and developing countries. International Journal of Multidisciplinary Research and Development, 4(6), 244251. Retrieved November 9, 2018, from 
http://www.allsubjectjournal.com/archives/ 2017/vol4/issue6.

Waste to energy in Denmark. (2006). The most efficient waste management system in Europe. Waste to energy in Denmark, RenoSam and Rambøll. Retrieved November 9, 2018, from https://stateofgreen.com/files/ download/275.

World Development Indicators. (2017). World Bank. Retrieved November 9, 2018, from http://data.worldbank.org/data-catalog/worlddevelopment-indicators.

Xu, L., Yu, B., \& Yue, W. (2010). A method of green GDP accounting based on eco-service and a case of study of Wuyishan, China. Procedia Environmental Sciences, 2, 1865-1872. https://doi.org/10.1016/j.proenv.2010.10.198.
Assistant Professor Saša Stjepanović, Ph.D. Juraj Dobrila University of Pula Faculty of Economics and Tourism "Dr. Mijo Mirković" Croatia sstjepan@unipu.hr

Associate Professor Daniel Tomić, Ph.D. Juraj Dobrila University of Pula Faculty of Economics and Tourism "Dr. Mijo Mirković" Croatia dtomic@unipu.hr

Full Professor Marinko Škare, Ph.D. Juraj Dobrila University of Pula Faculty of Economics and Tourism "Dr. Mijo Mirković" Croatia mskare@unipu.hr 


\section{Appendix: GDP growth rates vs. green GDP growth rates (in \%)}

\begin{tabular}{|c|c|c|c|c|c|c|c|c|c|c|c|c|c|c|c|c|}
\hline \multirow{2}{*}{$\begin{array}{c}\text { GDP } \\
\text { vs. } \\
\text { Green GDP }\end{array}$} & \multicolumn{2}{|c|}{2009} & \multicolumn{2}{|c|}{2010} & \multicolumn{2}{|c|}{2011} & \multicolumn{2}{|c|}{2012} & \multicolumn{2}{|c|}{2013} & \multicolumn{2}{|c|}{2014} & \multicolumn{2}{|c|}{2015} & \multicolumn{2}{|c|}{2016} \\
\hline & GDP & $\begin{array}{c}\text { Green } \\
\text { GDP }\end{array}$ & GDP & $\begin{array}{c}\text { Green } \\
\text { GDP }\end{array}$ & GDP & $\begin{array}{l}\text { Green } \\
\text { GDP }\end{array}$ & GDP & $\begin{array}{c}\text { Green } \\
\text { GDP }\end{array}$ & GDP & \begin{tabular}{|c|} 
Green \\
GDP
\end{tabular} & GDP & $\begin{array}{c}\text { Green } \\
\text { GDP }\end{array}$ & GDP & $\begin{array}{c}\text { Green } \\
\text { GDP }\end{array}$ & GDP & $\begin{array}{c}\text { Green } \\
\text { GDP }\end{array}$ \\
\hline Belgium & -6.57 & -7.15 & -0.21 & -0.91 & 8.99 & 8.63 & -5.53 & -5.89 & 4.63 & 4.27 & 1.95 & 1.62 & -14.29 & -14.67 & 2.80 & 2.42 \\
\hline Bulgaria & -4.64 & -6.43 & -2.46 & -4.74 & 13.45 & 11.04 & -6.12 & -8.52 & 3.44 & 1.47 & 1.75 & -0.18 & -11.52 & -13.69 & 6.05 & 3.78 \\
\hline Czech Rep. & -12.53 & -13.43 & 0.63 & -0.37 & 9.87 & 8.92 & -9.02 & -9.90 & 0.98 & 0.19 & -0.76 & -1.55 & -10.10 & -11.00 & 4.54 & 3.63 \\
\hline Denmark & -9.09 & \begin{tabular}{|l|}
-10.46 \\
\end{tabular} & 0.23 & -1.33 & 6.83 & 5.07 & -4.90 & -6.70 & 5.02 & 3.62 & 2.74 & 1.55 & \begin{tabular}{|l|}
-14.64 \\
\end{tabular} & \begin{tabular}{|l|}
-15.58 \\
\end{tabular} & 1.86 & 0.89 \\
\hline Estonia & 8.77 & \begin{tabular}{|l|}
-20.34 \\
\end{tabular} & -0.82 & -2.79 & 18.88 & 17.13 & -0.55 & -2.26 & 9.08 & 7.37 & 4.33 & 2.75 & -13.95 & \begin{tabular}{|l|}
-15.75 \\
\end{tabular} & 3.42 & 1.69 \\
\hline Germany & -8.91 & -9.32 & -0.03 & -0.45 & 9.97 & 9.57 & -5.69 & -6.11 & 5.88 & 5.49 & 3.68 & 3.32 & \begin{tabular}{|l|}
-13.24 \\
\end{tabular} & \begin{tabular}{|l|}
-13.64 \\
\end{tabular} & 3.03 & 2.62 \\
\hline Greece & -6.90 & -7.36 & -9.28 & -9.83 & -3.86 & -4.47 & 14.64 & 15.28 & -2.36 & -2.91 & -1.18 & -1.73 & -17.50 & \begin{tabular}{|l|}
-18.12 \\
\end{tabular} & -1.46 & -2.10 \\
\hline Ireland & -14.07 & -14.35 & -6.08 & -6.43 & 7.69 & 7.39 & -5.63 & -5.91 & 6.13 & 5.86 & 7.82 & 7.55 & 12.60 & 12.40 & 4.89 & 4.66 \\
\hline Spain & -8.31 & -8.63 & -4.50 & -4.83 & 3.94 & 3.62 & -10.22 & -10.59 & 1.93 & 1.60 & 1.11 & 0.79 & \begin{tabular}{|l|}
-13.01 \\
\end{tabular} & \begin{tabular}{|l|}
-13.39 \\
\end{tabular} & 3.29 & 2.89 \\
\hline France & -7.85 & -8.10 & -1.74 & -2.00 & 8.15 & 7.93 & -6.33 & -6.58 & 4.74 & 4.50 & 1.45 & 1.24 & \begin{tabular}{|l|}
-14.59 \\
\end{tabular} & \begin{tabular}{|l|}
-14.84 \\
\end{tabular} & 1.31 & 1.04 \\
\hline Croatia & -11.04 & \begin{tabular}{|l|}
-12.12 \\
\end{tabular} & -4.84 & -5.72 & 4.31 & 3.41 & -9.24 & -10.53 & 2.27 & 1.21 & -1.19 & -2.17 & -14.29 & \begin{tabular}{|l|}
-15.29 \\
\end{tabular} & 3.67 & 2.63 \\
\hline Italy & -8.60 & -9.00 & -2.75 & -3.18 & 7.12 & 6.69 & -8.94 & -9.43 & 2.78 & 2.32 & 1.00 & 0.57 & -14.84 & \begin{tabular}{|l|}
-15.30 \\
\end{tabular} & 1.45 & 0.96 \\
\hline Cyprus & -6.81 & -7.26 & -1.47 & -1.91 & 7.30 & 6.88 & -8.70 & -9.13 & -3.82 & -4.21 & -3.01 & -3.41 & \begin{tabular}{|l|}
-15.77 \\
\end{tabular} & \begin{tabular}{|l|}
-16.24 \\
\end{tabular} & 1.88 & 1.39 \\
\hline Latvia & 6.48 & -27.95 & -9.22 & -10.73 & 18.80 & 17.61 & -0.37 & -1.51 & 7.80 & 6.71 & 3.64 & 2.55 & \begin{tabular}{|l|}
-14.04 \\
\end{tabular} & \begin{tabular}{|l|}
-15.44 \\
\end{tabular} & 2.09 & 0.64 \\
\hline Lithuania & -21.75 & -22.40 & -0.86 & -1.56 & 17.12 & 16.49 & -1.45 & -2.10 & 8.46 & 7.89 & 4.46 & 3.90 & \begin{tabular}{|l|}
-14.71 \\
\end{tabular} & \begin{tabular}{|l|}
-15.36 \\
\end{tabular} & 3.23 & 2.56 \\
\hline Luxe & -8.02 & -8.34 & 3.59 & 3.27 & 12.76 & 12.46 & -5.54 & -5.85 & 8.93 & 8.67 & 7.43 & 7.20 & \begin{tabular}{|l|}
-12.88 \\
\end{tabular} & 13.16 & 1.47 & 1.18 \\
\hline Hunga & \begin{tabular}{|l|}
-17.34 \\
\end{tabular} & \begin{tabular}{|l|}
-18.23 \\
\end{tabular} & 0.25 & -0.58 & 7.53 & 6.67 & -9.18 & -10.13 & 5.76 & 4.96 & 3.63 & 2.89 & -12.30 & \begin{tabular}{|l|}
-13.03 \\
\end{tabular} & 2.39 & 1.63 \\
\hline Malta & -5.00 & -5.94 & 2.50 & 1.63 & 8.74 & 7.77 & -3.17 & -4.11 & 10.24 & 9.41 & 10.56 & 9.77 & -8.31 & -9.25 & 6.94 & 5.99 \\
\hline Netherlands & -8.36 & -9.28 & -2.51 & -3.23 & 6.86 & 6.00 & -7.25 & -8.56 & 4.55 & 3.33 & 1.49 & 0.47 & -13.83 & \begin{tabular}{|l|}
-14.64 \\
\end{tabular} & 2.54 & 1.71 \\
\hline Austria & -7.00 & -7.50 & -2.07 & -2.63 & 10.01 & 9.47 & -5.03 & -5.61 & 5.04 & 4.50 & 2.75 & 2.25 & \begin{tabular}{|l|}
-13.54 \\
\end{tabular} & \begin{tabular}{|l|}
-14.07 \\
\end{tabular} & 2.29 & 1.74 \\
\hline Poland & 17.51 & \begin{tabular}{|l|}
-18.82 \\
\end{tabular} & 8.84 & 7.48 & 10.32 & 8.96 & -5.38 & -6.73 & 4.78 & 3.57 & 3.98 & 2.86 & \begin{tabular}{|l|}
-12.44 \\
\end{tabular} & \begin{tabular}{|l|}
-13.69 \\
\end{tabular} & -1.24 & -2.61 \\
\hline Por & 97 & 9 & -2.23 & 0 & 2.77 & 24 & 11.65 & 2.19 & 4.49 & 3.97 & 1.57 & 1.07 & -13.16 & 13.71 & 2.72 & 2.15 \\
\hline Romania & .58 & -21.07 & 0.34 & 2 & 10.34 & 8 & -7.39 & 58 & 11.58 & & 15 & 66 & 0.82 & 2.12 & 5.44 & .12 \\
\hline Slovenia & -9.62 & \begin{tabular}{|l|}
-10.15 \\
\end{tabular} & -4.44 & -5.03 & 6.83 & 6.27 & -9.63 & \begin{tabular}{|l|}
-10.21 \\
\end{tabular} & 3.80 & 3.27 & 3.72 & 3.24 & \begin{tabular}{|l|}
-13.69 \\
\end{tabular} & \begin{tabular}{|l|}
-14.27 \\
\end{tabular} & 3.80 & 3.21 \\
\hline Slovak Rep. & -11.34 & \begin{tabular}{|l|}
-11.92 \\
\end{tabular} & 0.62 & -0.02 & 9.70 & 9.13 & -4.86 & -5.43 & 5.42 & 4.88 & 2.51 & 2.01 & \begin{tabular}{|l|}
-13.32 \\
\end{tabular} & \begin{tabular}{|l|}
-13.90 \\
\end{tabular} & 2.59 & 2.00 \\
\hline Finland & -11.36 & \begin{tabular}{|l|}
-12.05 \\
\end{tabular} & -1.47 & -2.44 & 10.44 & 9.45 & -6.20 & -7.16 & 5.17 & 4.32 & 0.97 & 0.14 & \begin{tabular}{|l|}
-14.74 \\
\end{tabular} & \begin{tabular}{|l|}
-15.67 \\
\end{tabular} & 2.61 & 1.65 \\
\hline Sweden & -16.40 & \begin{tabular}{|l|}
-17.01 \\
\end{tabular} & 13.67 & 12.93 & 15.30 & 14.65 & -3.41 & -4.03 & 6.41 & 5.79 & -0.85 & -1.42 & -13.23 & \begin{tabular}{|l|}
-13.94 \\
\end{tabular} & 3.32 & 2.60 \\
\hline UK & 7.57 & -18.61 & 2.45 & 1.36 & 7.31 & 6.18 & 1.62 & 0.60 & 2.92 & 2.06 & 10.33 & 9.65 & -4.54 & -5.06 & -8.24 & -8.85 \\
\hline Iceland & 6.95 & -28.45 & 2.85 & 1.71 & 10.71 & 9.65 & -3.11 & -4.23 & 8.87 & 7.69 & 10.98 & 9.90 & -2.30 & -3.56 & 19.45 & 18.29 \\
\hline Norway & \begin{tabular}{|l|}
-16.42 \\
\end{tabular} & -23.79 & 10.99 & 4.55 & 16.24 & 9.36 & 2.28 & -4.41 & 2.60 & -3.07 & -4.62 & -10.66 & -22.56 & -27.81 & -4.03 & -9.61 \\
\hline Montenegro & -8.50 & -9.32 & -0.48 & -1.69 & 9.64 & 8.50 & -9.93 & \begin{tabular}{|l|}
-11.02 \\
\end{tabular} & 9.21 & 8.2 & 2.77 & 1.81 & -11.66 & \begin{tabular}{|l|}
-12.71 \\
\end{tabular} & 7.93 & 6.82 \\
\hline Macedonia & -5.12 & -7.47 & 0.06 & -3.57 & 11.56 & 7.79 & -7.14 & -10.86 & 11.00 & 7.72 & 5.03 & 1.79 & -11.53 & \begin{tabular}{|l|}
-15.47 \\
\end{tabular} & 8.44 & 4.62 \\
\hline Albania & -6.50 & -7.37 & -0.97 & -2.48 & 8.08 & 5.72 & -4.43 & -7.12 & 3.71 & 0.79 & 3.54 & 0.54 & \begin{tabular}{|l|}
-14.31 \\
\end{tabular} & \begin{tabular}{|l|}
-16.37 \\
\end{tabular} & 4.66 & 2.52 \\
\hline Serbia & -13.49 & -15.21 & -7.41 & -9.54 & 17.76 & 15.62 & -12.32 & \begin{tabular}{|l}
-14.44 \\
\end{tabular} & 11.73 & 10.00 & -2.88 & -4.38 & -15.95 & \begin{tabular}{|l|}
-17.77 \\
\end{tabular} & 3.07 & 1.28 \\
\hline Turkey & -15.66 & -16.41 & 19.74 & 19.01 & 7.86 & 7.04 & 4.98 & 4.18 & 8.77 & 8.06 & -1.73 & -2.44 & -7.96 & -8.76 & 0.46 & -0.38 \\
\hline Moldova & \begin{tabular}{|l|}
-10.16 \\
\end{tabular} & \begin{tabular}{|l|}
-11.27 \\
\end{tabular} & 6.84 & 5.67 & 20.71 & 19.70 & 3.84 & 2.86 & 9.62 & 8.55 & -0.03 & -1.11 & \begin{tabular}{|l|}
-18.42 \\
\end{tabular} & \begin{tabular}{|l|}
-19.83 \\
\end{tabular} & 3.63 & 2.25 \\
\hline United States & -2.04 & -2.93 & 3.78 & 2.89 & 3.70 & 2.76 & 4.11 & 3.31 & 3.32 & 2.50 & 4.20 & 3.39 & 4.18 & 3.67 & 2.78 & 2.27 \\
\hline Australia & -12.14 & \begin{tabular}{|l|}
-15.47 \\
\end{tabular} & 23.27 & 19.72 & 21.67 & 18.24 & 10.62 & 7.98 & 1.88 & -0.67 & -6.86 & -9.50 & -7.83 & -9.74 & -10.46 & -12.67 \\
\hline Japan & 3.84 & 3.54 & 8.96 & 8.65 & 8.02 & 7.73 & 0.74 & 0.45 & \begin{tabular}{|l|}
-16.89 \\
\end{tabular} & -17.25 & -5.95 & -6.33 & -9.60 & \begin{tabular}{|l|}
-10.03 \\
\end{tabular} & 12.71 & 12.28 \\
\hline China & 11.13 & 5.25 & 19.39 & 13.29 & 24.13 & 18.03 & 13.05 & 8.85 & 12.23 & 8.76 & 9.11 & 6.41 & 5.55 & 3.54 & 1.22 & -0.94 \\
\hline Chile & -4.04 & -12.54 & 26.77 & 16.67 & 15.43 & 6.29 & 5.90 & -2.67 & 4.22 & -3.67 & -6.25 & -14.78 & -7.08 & \begin{tabular}{|l|}
-15.99 \\
\end{tabular} & 1.86 & -7.32 \\
\hline Israel & -3.90 & -4.37 & 12.63 & 12.20 & 11.99 & 11.55 & -1.66 & -2.16 & 13.68 & 13.20 & 5.45 & 5.01 & -3.02 & -3.45 & 6.23 & 5.81 \\
\hline Mexico & \begin{tabular}{|l|}
-18.74 \\
\end{tabular} & -22.75 & 17.45 & 13.12 & 11.42 & 5.82 & 1.32 & -4.25 & 6.35 & 1.66 & 2.89 & -1.07 & -11.26 & \begin{tabular}{|l|}
-13.68 \\
\end{tabular} & -9.14 & -11.92 \\
\hline Switzerland & -2.32 & -2.48 & 7.81 & 7.66 & 19.84 & 19.72 & -4.51 & -4.63 & 3.06 & 2.94 & 3.00 & 2.89 & -4.22 & -4.34 & -1.54 & -1.67 \\
\hline
\end{tabular}

Source: Authors' calculation

* Annual growth rates for Green GDP measure are calculated as the deviation from growth rates from the traditional GDP measure 


\title{
Abstract
}

\section{GREEN GDP: AN ANALYSES FOR DEVELOPING AND DEVELOPED COUNTRIES}

\author{
Saša Stjepanović, Daniel Tomić, Marinko Škare
}

A frequently asked question lately is whether the traditional measures of a country's level of economic activity and progress, such as gross domestic product or gross national product, fail to account for the environmental issues. While these measures are highly reliable indicators that reflect the economic performance of a country, they largely ignore the depreciation of assets, non-market economy and especially the damages to the environment caused by growth. There is a consensus that these indicators, (especially) according to the concepts of sustainable development and green growth, appear to be poor measurements. Measuring progress on a complex and multi-dimensional scale and identifying relevant indicators are challenging tasks. No agreement exists yet on an analytical framework or a set of indicators to sustainable economic growth. Building the research on the alternative Green GDP measurement our goal is to provide an alternative ranking scheme by comprehensively considering both quantitative (common methodological algorithm) and qualitative (opportunity costs) features of the so-called green growth. The analysis will be demonstrated by calculating the Green GDP indicator for the variety of developing and developed countries for the period 2008-2016. Namely, our results could serve to improve the level of debate on different green indicators and inform the wider public. We see this paper as a step forward for a growing academic platform on 'green economy topics', a step pointed towards improving, amending, evolving and promoting further development of green growth measurements and indicators.

Keywords: Green GDP, green growth, sustainable development, environment and ecology, a cross-country analysis.

JEL Classification: E01, O10, Q56.

DOI: 10.15240/tul/001/2019-4-001. 